\title{
Unusual case of occipital lobe dysembryoplastic neuroepithelial tumour with GNAi1-BRAF fusion
}

\author{
Jennifer H Yang, ${ }^{1}$ Denise M Malicki, ${ }^{2}$ Michael L Levy, ${ }^{3}$ John Ross Crawford ${ }^{4}$
}

'Department of Neurosciences, University of California San Diego, La Jolla, California, USA 2Pathology, Rady Children's Hospital University of California San Diego, San Diego,

California, USA

${ }^{3}$ Neurosurgery, University of California San Diego, San Diego, California, USA

${ }^{4}$ Neurosciences and Pediatrics, University of California San Diego, La Jolla, California, USA

Correspondence to Dr John Ross Crawford; jrcrawford@ucsd.edu

Accepted 13 January 2021

\section{Check for updates}

(c) BMJ Publishing Group Limited 2021. No commercial re-use. See rights and permissions. Published by BMJ.

To cite: Yang JH, Malicki DM, Levy ML, et al. BMJ Case Rep 2021;14:e241440. doi:10.1136/bcr-2020241440

\section{DESCRIPTION}

A previously healthy 9-year-old girl presented to otolaryngology clinic due to new onset bilateral sensorineural hearing loss. An MRI brain was ordered as part of her routine workup, and she was found to have an incidental $1.3 \mathrm{~cm}$ nonenhancing T1 hypointense, T2 hyperintense mass in the right occipital lobe just superior to the tentorium without associated diffusion restriction. The patient otherwise denied any problems with vision, nausea, vomiting or seizures. Her neurological examination was normal other than the sensorineural hearing loss confirmed on audiometry, which was likely unrelated to the imaging findings. Given the imaging appearance, a low-grade glioma was suspected, and she was monitored closely with sequential MRI. However, follow-up imaging 2 years later showed a slight increase in tumour size with new heterogeneous enhancement (figure 1). At that time, the patient underwent gross total resection. Permanent sections showed a proliferation of bland, occasionally process-forming cells in a largely myxoid background with microcyst formation, scattered 'floating' neurons within pools of mucin and increased mitotic activity. Findings were most consistent with a dysembryoplastic neuroepithelial tumour (DNET). ${ }^{1}$ Immunohistochemistry demonstrated NeuN-positive scattered neurons corresponding to the floating neurons noted on H\&E staining, diffusely positive glial fibrillar acidic

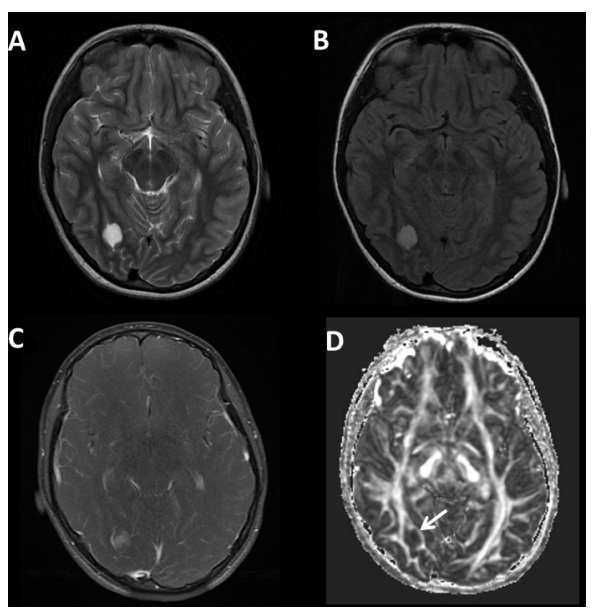

Figure 1 MRI brain demonstrates a well-circumscribed, T2 hyperintense (A) and T2 FLAIR hyperintense (B) mass in the right occipital lobe, with post-contrast showing heterogeneous enhancement (C), and fractional anisotropy on diffusion tensor imaging showing fibre displacement of the right optic radiation on both sides of the lesion (D).

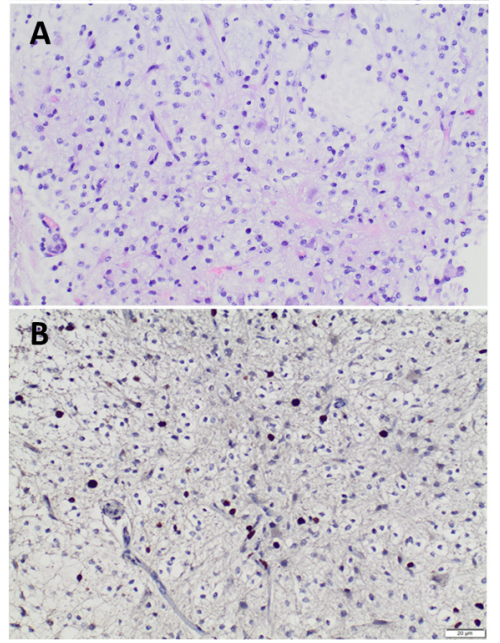

Figure 2 H\&E stained sections showing a proliferation predominantly of bland, occasionally process-forming cells in a largely myxoid background with microcyst formation and scattered 'floating' neurons with mitotic activity noted (A), and Ki-67 staining showing 3\%$5 \%$ nuclear labelling (B).

protein (GFAP) staining and 3\%-5\% Ki67 positivity (figure 2). Next-generation sequencing with solid tumour mutation panel analysis revealed a GNAi1$B R A F$ fusion, and a microarray demonstrated chromothripsis of chromosome 7 with nine segmental gains and breakages at 7q34 in KIAA1549.

DNETs are WHO grade I low-grade gliomas more commonly seen in children that often present with focal epilepsy. ${ }^{2}$ BRAF p.V600E mutations, FGFR1 alterations and BRAF-KIAA1549 fusion are more commonly reported, although the incidences vary among different studies. ${ }^{3-5}$ In addition, copy number alterations, most frequently copy number gains in chromosomes 5 and 7, are reported in DNETs, although they do not correlate with specific histological subtypes. ${ }^{16}$ We report an unusual occipital low-grade glioma with histological characteristics of a DNET and genetics demonstrating a GNAi1-BRAF fusion which has been reported at very low frequencies compared with the more common KIAA1549-BRAF fusions in cerebellar juvenile pilocytic astrocytoma. However, our reported case of GNAi1-BRAF has not been previously described in DNETs. The rare GNAi1$B R A F$ fusion represents an activating mutation that may potentially be amenable to targeted therapies. ${ }^{7}$ Thus, molecular stratification with next-generation sequencing can aid in tumour classification and further characterise phenotype-genotype correlation to better guide clinical management. 


\section{Learning points}

- Dysembryoplastic neuroepithelial tumours (DNETs) are predominantly paediatric low-grade gliomas that may or may not present with focal neurological symptoms.

- GNAi1-BRAF fusion has not been previously reported in patients with DNETs, thus adding to the genotypic variation of this heterogeneous group of tumours.

- Next-generation sequencing can provide additional tumour characterisation and guide future studies in phenotypegenotype correlations.

Contributors JHY was responsible for the writing of the manuscript. DMM was responsible for the writing of the manuscript. MLL was responsible for the writing of the manuscript. JRC was responsible for the writing of the manuscript.

Funding The authors have not declared a specific grant for this research from any funding agency in the public, commercial or not-for-profit sectors.

Competing interests None declared.
Patient consent for publication Parental/guardian consent obtained.

Provenance and peer review Not commissioned; externally peer reviewed.

\section{REFERENCES}

1 Suh Y-L. Dysembryoplastic neuroepithelial tumors. J Pathol Trans/ Med 2015:49:438-49.

2 Chassoux F, Landré E, Mellerio C, et al. Dysembryoplastic neuroepithelial tumors: epileptogenicity related to histologic subtypes. Clin Neurophysiol 2013;124:1068-78.

3 Ryall S, Zapotocky M, Fukuoka K, et al. Integrated molecular and clinical analysis of 1,000 pediatric low-grade gliomas. Cancer Cell 2020;37:569-83.

4 Chappé C, Padovani L, Scavarda D, et al. Dysembryoplastic neuroepithelial tumors share with pleomorphic xanthoastrocytomas and gangliogliomas BRAF(V600E) mutation and expression. Brain Pathol 2013;23:574-83.

5 Gierke M, Sperveslage J, Schwab D, et al. Analysis of IDH1-R132 mutation, BRAF V600 mutation and KIAA1549-BRAF fusion transcript status in central nervous system tumors supports pediatric tumor classification. J Cancer Res Clin Oncol 2016;142:89-100.

6 Chiang JC, Ellison DW. Molecular pathology of paediatric central nervous system tumours. J Pathol 2017;241:159-72.

7 Jain P, Silva A, Han HJ, et al. Overcoming resistance to single-agent therapy for oncogenic BRAF gene fusions via combinatorial targeting of MAPK and PI3K/mTOR signaling pathways. Oncotarget 2017:8:84697-713.

Copyright 2021 BMJ Publishing Group. All rights reserved. For permission to reuse any of this content visit

https://www.bmj.com/company/products-services/rights-and-licensing/permissions/

BMJ Case Report Fellows may re-use this article for personal use and teaching without any further permission.

Become a Fellow of BMJ Case Reports today and you can:

- Submit as many cases as you like

- Enjoy fast sympathetic peer review and rapid publication of accepted articles

- Access all the published articles

Re-use any of the published material for personal use and teaching without further permission

Customer Service

If you have any further queries about your subscription, please contact our customer services team on +44 (0) 2071111105 or via email at support@bmj.com.

Visit casereports.bmj.com for more articles like this and to become a Fellow 